Article

\title{
Association of Dietary Patterns with Components of Metabolic Syndrome and Inflammation among Middle-Aged and Older Adults with Metabolic Syndrome in Taiwan
}

\author{
Ahmad Syauqy ${ }^{1,2}$, Chien-Yeh Hsu ${ }^{3,4}$, Hsiao-Hsien Rau ${ }^{5}$ and Jane C.-J. Chao ${ }^{1,4,6, *}$ \\ 1 School of Nutrition and Health Sciences, College of Nutrition, Taipei Medical University, \\ 250 Wu-Hsing Street, Taipei 11031, Taiwan; syauqy@fk.undip.ac.id \\ 2 Department of Nutrition Science, Faculty of Medicine, Diponegoro University, Jl. Prof. H. Soedarto, SH., \\ Tembalang, Semarang City, Central Java 50275, Indonesia \\ 3 Department of Information Management, National Taipei University of Nursing and Health Sciences, \\ 365 Ming-Te Road, Peitou District, Taipei 11031, Taiwan; cyhsu@ntunhs.edu.tw \\ 4 Master Program in Global Health and Development, College of Public Health, Taipei Medical University, \\ $250 \mathrm{Wu}$-Hsing Street, Taipei 11031, Taiwan \\ 5 Graduate Institute of Biomedical Informatics, College of Medical Technology, Taipei Medical University, \\ 250 Wu-Hsing Street, Taipei 11031, Taiwan; rauhhh@gmail.com \\ 6 Nutrition Research Center, Taipei Medical University Hospital, 252 Wu-Hsing Street, Taipei 11031, Taiwan \\ * Correspondence: chenjui@tmu.edu.tw; Tel.: +886-2-2736-1661 (ext. 6548); Fax: +886-2-2736-3112
}

Received: 28 November 2017; Accepted: 25 January 2018; Published: 29 January 2018

\begin{abstract}
This study examined the correlation of dietary patterns with components of metabolic syndrome (MetS) and inflammation among middle-aged and older adults with MetS in Taiwan. This cross-sectional study used data from the Mei Jau International Health Management Institution in Taiwan between 2004 and 2013. A total of 26,016 subjects aged 35 years and above were selected for analysis. MetS was defined according to the International Diabetes Federation. Three dietary patterns were identified by principal component analysis. High intake of a meat-instant food dietary pattern (rich in animal protein, saturated fat, sweets, sodium, and food additives) was positively associated with components of MetS and C-reactive protein (CRP), while high intake of a vege-seafood dietary pattern (rich in dietary fiber, vitamins, minerals, and unsaturated fat) or a cereal-dairy dietary pattern (rich in dietary fiber, antioxidants, phytochemicals, complex carbohydrate, prebiotics, and probiotics) was inversely associated with components of MetS and CRP. Our findings suggested that intake of a vege-seafood dietary pattern or a cereal-dairy dietary pattern decreased the risk of developing MetS and inflammation among middle-aged and older adults with MetS.
\end{abstract}

Keywords: dietary patterns; metabolic syndrome; inflammation; Taiwan

\section{Introduction}

The International Diabetes Federation (IDF) defines metabolic syndrome (MetS) as a cluster of conditions characterized by central obesity with two of the following four factors: elevated blood pressure, reduced high-density lipoprotein-cholesterol (HDL-C), elevated blood serum triacylglycerol (TG), and elevated fasting plasma glucose (FPG). Central obesity is considered to be the underlying cause of MetS, as it is associated with insulin resistance and contributes to MetS and its components [1]. MetS has been considered as a significant determinant of cardiovascular diseases (CVDs). Recently, CVD—a major public health concern throughout the world—contributed to 30\% of deaths worldwide [2]. People with MetS are also more likely to have inflammation that could 
potentially aggravate the incidence of CVD [3,4]. Furthermore, the prevalence of MetS has significantly increased in all regions around the world [5-10]. A previous study conducted in China found that the prevalence of MetS was 24.5\% in 2016 [11]; in Taiwan, a study using the Nutrition and Health Survey in Taiwan (NAHSIT) showed an increasing trend of MetS from 13.6\% to 25.5\% from NAHSIT 1993-1996 to NAHSIT 2005-2008, respectively [12]. The prevalence of central obesity also increased with age in Taiwan. The prevalence of central obesity in Taiwanese people aged from 30 to 39 years old was $27.0 \%$ in men and $16.4 \%$ in women; furthermore, the prevalence increased considerably in Taiwanese people aged from 70 to 79 years old, $42.9 \%$ and $64.6 \%$ for men and women, respectively [13].

Many factors such as demographics and lifestyle are known to be involved in the etiology of MetS [14]. Among these factors, dietary patterns have demonstrated an important role in the increased prevalence of MetS $[15,16]$. When evaluating the association of diet and disease, dietary patterns consisting of complex foods with many nutrients are more prominent influencing factors than single nutrients or diet items. Hence, holistic dietary patterns are considered to be better at preventing the development of diseases than single foods [17]. Healthy dietary patterns such as the traditional unrefined diet and the Mediterranean diet (which are both characterized as rich in vegetables, fruit, whole grains, cereal, fish and seafood products), as well as the low-fat diet, showed positive association with the components of MetS. A previous study found that a diet containing more fruit, vegetables, and whole grains decreased MetS and inflammation [18]. However, unhealthy dietary patterns including the Western dietary pattern-characterized as rich in red meat, organ meat, processed foods, and high-fat foods - was negatively associated with MetS [19-22]. Moreover, the Western dietary pattern might increase the risk of MetS and promote the production of pro-inflammatory markers [23].

Some studies have investigated the correlation between dietary patterns and diseases. Previous studies showed a significant correlation of dietary patterns with CVD [24] and cognitive function [25] in Taiwanese middle-aged and/or older adults. Additionally, people who ate more fruit and vegetables and less animal-derived foods had a better quality of life and less total health care costs in Taiwan [26]. A review study on the metabolic health effect of dietary habits among middle-aged and older adults has been discussed [27]. However, no study has been found that clarifies the association of dietary patterns with MetS and inflammation in Taiwan. The objective of this study was to investigate the correlation of dietary patterns with components of MetS and inflammation among middle-aged and older adults with MetS in Taiwan.

\section{Materials and Methods}

\subsection{Study Design}

This study was performed using a cross-sectional design to analyze data from the Mei Jau (MJ) International Health Management Institution in Taiwan between 2004 and 2013. The MJ International Health Management Institution is an independent health screening and management institution in Taiwan. It has four screening centers (Taipei city, Taoyuan city, Taichung city, and Kaohsiung city). They offer comprehensive health screenings for individuals who seek health check-ups. All participants who came to the MJ screening centers were from the general population. When visiting the screening centers, prior to undergoing a health examination, the participants of the study agreed to answer a structured questionnaire and signed a consent form, which allowed the MJ International Health Management Institution to collect the data for research use only without their personal information. All data were collected by MJ health screening centers. The health screening centers have been defined clearly in previous studies [24,28]. This study was approved by the Taiwan Medical University-Joint Institutional Review Board (N201706051).

\subsection{Data Collection}

We retrieved 60,769 subjects who were aged 35 years and above and met MetS criteria from the MJ database between 2004 and 2013. Among 37,392 subjects, after excluding subjects $(n=23,377)$ who 
had cancer, liver disorder, or renal disease, and 11,376 subjects with missing data, a total of 26,016 subjects were analyzed in this study.

\subsection{Definition of MetS and Inflammation}

The International Diabetes Federation defines individuals with MetS as those who had central obesity based on race- and gender-specific waist circumferences ( $\geq 90 \mathrm{~cm}$ in men or $\geq 80 \mathrm{~cm}$ in women in Taiwan) and two of the following four factors: (1) elevated systolic blood pressure $\geq 130 \mathrm{mmHg}$ or diastolic blood pressure $\geq 85 \mathrm{mmHg}$ or on treatment for previously diagnosed hypertension; (2) reduced HDL-C $<40 \mathrm{mg} / \mathrm{dL}(1.03 \mathrm{mmol} / \mathrm{L})$ in men or $<50 \mathrm{mg} / \mathrm{dL}(1.29 \mathrm{mmol} / \mathrm{L})$ in women, or a history of specific treatment for this lipid abnormality; (3) elevated blood serum TG $\geq 150 \mathrm{mg} / \mathrm{dL}$ $(1.7 \mathrm{mmol} / \mathrm{L})$ or a history of specific treatment for this lipid abnormality; (4) elevated FPG $\geq 100 \mathrm{mg} / \mathrm{dL}$ ( $\geq 5.60 \mathrm{mmol} / \mathrm{L}$ ) or previously diagnosed type 2 diabetes mellitus [1]. Additionally, C-reactive protein $(\mathrm{CRP}) \geq 28.6 \mathrm{nmol} / \mathrm{L}$ was defined as inflammation [29].

\subsection{Demographic, Lifestyle, and Anthropometric Measurements}

The demographic and lifestyle data such as age, gender, education, marital status, smoking, and drinking were obtained using the individual questionnaire, which was conducted when the subjects visited MJ health screening centers before health check-ups [24]. The height, weight, body mass index, and waist circumference were measured during the health check-up as described previously [28].

\subsection{Blood Pressure and Biochemical Assessment}

After overnight fasting for 12-14 h, systolic and diastolic blood pressure were assessed, and blood samples were collected. Total cholesterol, HDL-C, serum TG, FPG, and CRP concentrations were analyzed using commercial reagents [24], whereas low-density lipoprotein-cholesterol (LDL-C) levels were calculated using the formula [30]. All parameters were measured at the central laboratory of the MJ International Health Management Institution.

\subsection{Dietary Assessment}

A validated food frequency questionnaire (FFQ) was used to analyze dietary consumption. The FFQ had 22 food items based on the features of Taiwanese dietary patterns, and each question had five options for the frequency of consumption as servings per day or per week from the lowest to the highest, as described previously [24]. The subjects completed the FFQ before the health check-up at the MJ health screening centers.

\subsection{Statistical Analysis}

Dietary patterns were identified by principal component analysis (PCA). We used orthogonal rotation with the Kaiser criterion (eigenvalues $>1.5$ ) to define dietary patterns [31]. The factor loading of $\geq 0.30$ was used in the classification of dietary patterns. If the food item had a factor loading of $\geq 0.30$ in different dietary patterns, the dietary pattern was identified by which one had a higher factor loading. Factor scores of dietary patterns for each individual summed up the intake of food items weighed by factor loadings, and then classified into tertiles. A chi-square test was used for categorical variables to compare the differences between the characteristics of the subjects and tertiles of dietary pattern scores, while a one-way analysis of variance and the Bonferroni post-hoc test were used to compare continuous variables. A crude or adjusted odds ratio (OR), $95 \%$ confidence intervals (CIs), and a multivariable logistic regression model were performed to evaluate the associations of dietary patterns across tertiles of scores with the components of metabolic syndrome and CRP. In the regression model, we categorized the components of MetS and CRP as a high level of mean waist circumference ( $\geq 95.8 \mathrm{~cm}$ for males and $\geq 85.2 \mathrm{~cm}$ for females), a high level of systolic blood pressure (BP; $\geq 130 \mathrm{mmHg}$ ), a high level of diastolic BP ( $\geq 85 \mathrm{mmHg}$ ), a low level of HDL-C ( $<1.03 \mathrm{mmol} / \mathrm{L}$ for 
males and $<1.29 \mathrm{mmol} / \mathrm{L}$ for females), a high level of serum TG ( $\geq 1.70 \mathrm{mmol} / \mathrm{L})$, a high level of FPG $(\geq 5.60 \mathrm{mmol} / \mathrm{L})$, and a high level of CRP $(\geq 28.6 \mathrm{nmol} / \mathrm{L})$. All models were adjusted for age, gender (except waist circumference and HDL-C), education, marital status, smoking, and drinking. The first tertile of dietary pattern scores was considered as a reference. Statistical analyses were conducted using SPSS 24 (IBM Corp., Armonk, NY, USA). Categorical variables are presented as a number (percentage) and continuous variables are presented as a mean \pm standard deviation (SD) with $p$ values $<0.05$ as significant.

\section{Results}

Among 26,016 subjects with MetS, 41.9\% and 22.1\% had elevated systolic and diastolic blood pressure, respectively, 25.1\% had reduced HDL-C, 50.3\% had elevated serum TG, 70.1\% had abnormal FPG, and $38.8 \%$ had elevated CRP (table not shown).

\subsection{Dietary Patterns}

Three dietary patterns identified by PCA are shown in Table 1 . The three dietary patterns were derived as the meat-instant food dietary pattern, the vege-seafood dietary pattern, and the cereal-dairy dietary pattern. The three dietary patterns explained $33.45 \%$ of total variance. The meat-instant food dietary pattern, the vege-seafood dietary pattern, and the cereal-dairy dietary pattern explained $16.89 \%, 9.42 \%$, and $7.14 \%$ of variance, respectively. The meat-instant food dietary pattern included 10 food items: eggs (i.e., chicken eggs, duck eggs, and quail eggs), meat (i.e., pork, chicken, duck, beef, veal, and lamb), organ meats (i.e., liver, kidneys, and heart), refined dessert (i.e., butter bread, cake, and cookies), sugary drinks, rice/flour cooked in oil (i.e., fried rice and fried noodles), deep-fried food, instant noodle, processed food (i.e., ham, sausage, and canned food), and sauce (i.e., soy sauce, ketchup, hot sauce, and vinegar). The vege-seafood dietary pattern contained six food items: light- or dark-colored vegetables (i.e., carrot, spinach, squash, tomato, cabbage, pechay, cucumber, and radish), fruit, vegetables with oil/dressing, legumes/soy products (i.e., tofu, soybean milk, and dried bean curd), and seafood (i.e., fish, shrimp, and shells). The cereal-dairy dietary pattern included six food items: rice/flour products (i.e., rice, noodle, plain bread, and cruller), whole grains (i.e., whole wheat bread, brown rice, mixed grains, and oatmeal), root crops (i.e., potato, taro, and corn), jam/honey, milk (i.e., fresh milk and powdered milk), and dairy products (i.e., yogurt and cheese).

\subsection{Characteristics of the Subjects and Dietary Patterns}

The characteristics of the subjects across the tertiles of the dietary patterns are summarized in Table 2. Subjects with the higher tertile of the meat-instant food dietary pattern were more likely to be men, younger, current smokers, and drinking at least twice a week, and had adverse components of MetS and higher CRP $(p<0.01)$. On the contrary, subjects with the higher tertile of the vege-seafood dietary pattern or the cereal-dairy dietary pattern had an opposite tendency; they were female, older, not current smokers, and not drinking, and had better components of MetS and lower CRP $(p<0.01)$.

\subsection{Dietary Patterns, Metabolic Syndrome, and Inflammatory Marker}

The odds ratios of the components of MetS and CRP across tertiles of dietary patterns are shown in Table 3, while the association between the components of MetS and CRP are demonstrated in Table S1. The highest tertile (T3) of the meat-instant food dietary pattern was significantly associated with increased crude odds (model 1) of a high level of waist circumference ( $\geq$ mean of $95.8 \mathrm{~cm}$ for male and $\geq$ mean of $85.2 \mathrm{~cm}$ for female), a high level of systolic blood pressure ( $\geq 130 \mathrm{mmHg}$ ), a low level of HDL-C ( $<1.03 \mathrm{mmol} / \mathrm{L}$ for male and $<1.29 \mathrm{mmol} / \mathrm{L}$ for female), a high level of serum TG $(\geq 1.70 \mathrm{mmol} / \mathrm{L})$, a high level of FPG $(\geq 5.60 \mathrm{mmol} / \mathrm{L})$, and a high level of CRP $(\geq 28.6 \mathrm{nmol} / \mathrm{L})$ compared to the lowest tertile (T1). After adjusting for age, gender, education, marital status, smoking, and drinking (model 2), only a high level of systolic blood pressure ( $\geq 130 \mathrm{mmHg}$ ) was not significantly correlated with the meat-instant food dietary pattern between the highest tertile and the lowest one. 
In contrast, the highest tertile of the vege-seafood dietary pattern was significantly associated with decreased odds of a high level of waist circumference ( $\geq$ mean of $95.8 \mathrm{~cm}$ for male and $\geq$ mean of $85.2 \mathrm{~cm}$ for female), a high level of systolic blood pressure ( $\geq 130 \mathrm{mmHg})$, a high level of diastolic blood pressure ( $\geq 85 \mathrm{mmHg})$, a low level of HDL-C ( $<1.03 \mathrm{mmol} / \mathrm{L}$ for male and $<1.29 \mathrm{mmol} / \mathrm{L}$ for female), a high level of serum TG ( $\geq 1.70 \mathrm{mmol} / \mathrm{L})$, a high level of FPG $(\geq 5.60 \mathrm{mmol} / \mathrm{L})$, and a high level of CRP $(\geq 28.6 \mathrm{nmol} / \mathrm{L})$ compared to the lowest tertile in both unadjusted and adjusted models. Similarly, the highest tertile of the cereal-dairy dietary pattern was significantly correlated with decreased odds of a high level of waist circumference (mean of $\geq 95.8 \mathrm{~cm}$ for male and mean of $\geq 85.2 \mathrm{~cm}$ for female), a high level of diastolic blood pressure $(\geq 85 \mathrm{mmHg})$, a low level of HDL-C $(<1.03 \mathrm{mmol} / \mathrm{L}$ for male and $<1.29 \mathrm{mmol} / \mathrm{L}$ for female), a high level of serum TG ( $\geq 1.70 \mathrm{mmol} / \mathrm{L})$, a high level of FPG $(\geq 5.60 \mathrm{mmol} / \mathrm{L})$, and a high level of CRP $(\geq 28.6 \mathrm{nmol} / \mathrm{L})$ compared to the lowest tertile in both models.

In Table 3, we did not analyze the association between dietary patterns and body mass index in different genders because we only analyzed the components of MetS and waist circumference as indicators of central obesity, which were included in the components of MetS. The results showed that the association between dietary patterns and waist circumference was statistically significant with similar tendencies in both genders, indicating that there was no gender difference. Moreover, we used the IDF's definition of MetS, which mentioned that waist circumference was the first criteria to define MetS (male $\geq 90 \mathrm{~cm}$, female $\geq 80 \mathrm{~cm}$ ) in Taiwan; therefore, all subjects had central obesity and we cannot find the odds ratios of waist circumference. Hence, we used mean waist circumference in the table to calculate the odds ratios for both genders.

Table 1. Factor loadings and dietary patterns derived by principal component analysis for the 22 food groups.

\begin{tabular}{cccc}
\hline Food Groups & $\begin{array}{c}\text { Factor I } \\
\text { Meat-Instant Food } \\
\text { Dietary Pattern }\end{array}$ & $\begin{array}{c}\text { Factor II } \\
\text { Vege-Seafood Dietary } \\
\text { Pattern }\end{array}$ & $\begin{array}{c}\text { Factor III } \\
\text { Cereal-Dairy Dietary } \\
\text { Pattern }\end{array}$ \\
\hline Milk & -0.174 & 0.047 & 0.597 \\
Dairy products & 0.038 & 0.058 & 0.634 \\
Eggs & 0.471 & 0.131 & 0.154 \\
Meat & 0.552 & 0.265 & -0.037 \\
Organ meats & 0.313 & 0.127 & 0.036 \\
Legumes/soy products & 0.331 & 0.354 & 0.146 \\
Seafood & 0.312 & 0.400 & 0.070 \\
Light-colored vegetables & -0.055 & 0.815 & 0.078 \\
Dark-colored vegetables & -0.084 & 0.841 & 0.080 \\
Fruit & -0.063 & 0.440 & 0.355 \\
Vegetables with oil/dressing & 0.278 & 0.569 & -0.053 \\
Rice/flour products & 0.295 & -0.011 & 0.521 \\
Whole grains & -0.039 & 0.089 & 0.441 \\
Root crops & 0.126 & 0.241 & 0.397 \\
Refined dessert & 0.327 & 0.226 & -0.079 \\
Jam/honey & 0.317 & -0.066 & 0.453 \\
Sugary drinks & 0.524 & -0.173 & 0.154 \\
Rice/flour cooked in oil & 0.405 & 0.011 & 0.238 \\
Deep-fried food & 0.674 & 0.111 & -0.030 \\
Instant noodle & 0.397 & -0.115 & -0.009 \\
Processed food & 0.611 & 0.051 & 0.053 \\
Sauce & 0.549 & 0.076 & -0.035 \\
\hline
\end{tabular}


Table 2. Characteristics of the subjects across tertiles of dietary patterns $(n=26,016)^{1}$.

\begin{tabular}{|c|c|c|c|c|c|c|c|c|c|c|c|c|}
\hline \multirow{2}{*}{ Variables } & \multicolumn{3}{|c|}{ Meat-Instant Food Dietary Pattern } & \multirow{2}{*}{$p^{2}$} & \multicolumn{3}{|c|}{ Vege-Seafood Dietary Pattern } & \multirow{2}{*}{$p^{2}$} & \multicolumn{3}{|c|}{ Cereal-Dairy Dietary Pattern } & \multirow{2}{*}{$p^{2}$} \\
\hline & T1 & T2 & T3 & & T1 & T2 & T3 & & T1 & T2 & T3 & \\
\hline$n$ & 8626 & 8754 & 8636 & & 8640 & 8752 & 8624 & & 8645 & 8741 & 8630 & \\
\hline $\begin{array}{l}\text { Factor scores of dietary } \\
\text { patterns }\end{array}$ & -2.67 to -0.5 & $>-0.5$ to 0.27 & $>0.27$ to 5.29 & & $\begin{array}{c}-3.27 \text { to } \\
-0.37\end{array}$ & $>-0.37$ to 0.26 & $>0.26$ to 4.79 & & $\begin{array}{c}-2.63 \text { to } \\
-0.51\end{array}$ & $>-0.51$ to 0.31 & $>0.31$ to 5.54 & \\
\hline Males & $3897(45.2)$ & $4996(57.1)$ & $5532(65.2)$ & 0.000 & $5141(59.5)$ & $4790(54.8)$ & $4594(53.3)$ & 0.000 & $5074(58.7)$ & 5007 (57.3) & $4444(51.5)$ & 0.000 \\
\hline Age (years) & $56.3 \pm 11.7$ & $54.0 \pm 11.4$ & $50.3 \pm 11.4$ & 0.000 & $52.5 \pm 11.9$ & $53.5 \pm 11.5$ & $54.6 \pm 11.8$ & 0.000 & $52.8 \pm 11.5$ & $53.5 \pm 11.6$ & $54.2 \pm 12.2$ & 0.000 \\
\hline $\begin{aligned} & \text { Education } \\
& \leq \text { High school } \\
&>\text { High school }\end{aligned}$ & $\begin{array}{l}4993(57.9) \\
3633(42.1)\end{array}$ & $\begin{array}{l}4711(53.8) \\
4043(46.2)\end{array}$ & $\begin{array}{l}3985(46.1) \\
4651(53.9)\end{array}$ & 0.000 & $\begin{array}{l}4455(51.6) \\
4185(48.4)\end{array}$ & $\begin{array}{l}4574(52.3) \\
4178(47.7)\end{array}$ & $\begin{array}{l}4660(54.0) \\
3964(46.0)\end{array}$ & 0.004 & $\begin{array}{l}4967(57.5) \\
3678(42.5)\end{array}$ & $\begin{array}{l}4443(50.8) \\
4298(49.2)\end{array}$ & $\begin{array}{l}4279(49.6) \\
4351(50.4)\end{array}$ & 0.000 \\
\hline $\begin{array}{c}\text { Marital status } \\
\text { Never married } \\
\text { Married } \\
\text { Divorced/widowed }\end{array}$ & $\begin{array}{c}199(2.3) \\
7048(81.7) \\
1379(16.0)\end{array}$ & $\begin{array}{c}222(2.5) \\
7531(86.0) \\
1001(11.5)\end{array}$ & $\begin{array}{c}405(4.7) \\
7398(85.7) \\
833(9.6)\end{array}$ & 0.000 & $\begin{array}{c}358(4.2) \\
7184(83.1) \\
1098(12.7)\end{array}$ & $\begin{array}{c}280(3.2) \\
7437(85.0) \\
1035(11.8)\end{array}$ & $\begin{array}{c}188(2.2) \\
7356(85.3) \\
1080(12.5)\end{array}$ & 0.000 & $\begin{array}{c}291(3.4) \\
7250(83.8) \\
1104(12.8)\end{array}$ & $\begin{array}{c}247(2.8) \\
7495(85.8) \\
999(11.4)\end{array}$ & $\begin{array}{c}288(3.3) \\
7232(83.8) \\
1110(12.9)\end{array}$ & 0.002 \\
\hline $\begin{array}{c}\text { Current smoker } \\
\text { No } \\
\text { Yes }\end{array}$ & $\begin{array}{l}8333(96.6) \\
293(3.4)\end{array}$ & $\begin{array}{l}8431(96.3) \\
323(3.7)\end{array}$ & $\begin{array}{l}8250(95.5) \\
379(4.5)\end{array}$ & 0.001 & $\begin{array}{l}8256(95.6) \\
384(4.4)\end{array}$ & $\begin{array}{l}8416(96.2) \\
336(3.8)\end{array}$ & $\begin{array}{l}8342(96.7) \\
282(3.3)\end{array}$ & 0.000 & $\begin{array}{c}8219(95.1) \\
426(4.9)\end{array}$ & $\begin{array}{l}8391(96.0) \\
350(4.0)\end{array}$ & $\begin{array}{l}8404(97.4) \\
226(2.6)\end{array}$ & 0.000 \\
\hline $\begin{array}{c}\text { Drinking } \\
<2 \text { times/week } \\
\geq 2 \text { times/week }\end{array}$ & $\begin{array}{c}8275(95.9) \\
351(4.1) \\
\end{array}$ & $\begin{array}{c}8373(95.6) \\
381(4.4)\end{array}$ & $\begin{array}{c}8181(94.7) \\
455(5.3) \\
\end{array}$ & 0.000 & $\begin{array}{c}8205(95.0) \\
435(5.0) \\
\end{array}$ & $\begin{array}{c}8351(95.4) \\
401(4.6) \\
\end{array}$ & $\begin{array}{c}8273(95.9) \\
351(4.1) \\
\end{array}$ & 0.01 & $\begin{array}{c}8152(94.3) \\
493(5.7) \\
\end{array}$ & $\begin{array}{c}8340(95.4) \\
401(4.6) \\
\end{array}$ & $\begin{array}{c}8337(96.6) \\
293(3.4) \\
\end{array}$ & 0.000 \\
\hline $\operatorname{BMI}\left(\mathrm{kg} / \mathrm{m}^{2}\right)$ & $27.1 \pm 2.6$ & $27.2 \pm 2.6$ & $27.2 \pm 2.7$ & 0.000 & $27.4 \pm 2.7$ & $27.1 \pm 2.6$ & $27.1 \pm 2.7$ & 0.000 & $27.3 \pm 2.7$ & $27.3 \pm 2.6$ & $27.0 \pm 2.6$ & 0.000 \\
\hline $\mathrm{WC}(\mathrm{cm})$ & $89.1 \pm 6.6$ & $91.1 \pm 6.6$ & $93.2 \pm 8.6$ & 0.000 & $92.3 \pm 8.6$ & $90.6 \pm 6.5$ & $90.5 \pm 7.1$ & 0.000 & $91.9 \pm 8$ & $91.7 \pm 7.7$ & $89.8 \pm 6.2$ & 0.000 \\
\hline Systolic BP (mmHg) & $118.5 \pm 39.4$ & $120.8 \pm 35.2$ & $121.1 \pm 33.7$ & 0.000 & $121.2 \pm 35.9$ & $120.6 \pm 34.7$ & $118.8 \pm 37.9$ & 0.000 & $122.6 \pm 34.7$ & $119.9 \pm 36.2$ & $117.8 \pm 37.5$ & 0.000 \\
\hline Diastolic BP (mmHg) & $70.3 \pm 23.5$ & $72.3 \pm 21.1$ & $72.4 \pm 20.7$ & 0.000 & $72.4 \pm 21.9$ & $71.6 \pm 20.8$ & $71.1 \pm 22.7$ & 0.001 & $72.7 \pm 20.6$ & $72.1 \pm 22.1$ & $70.2 \pm 22.6$ & 0.000 \\
\hline $\mathrm{TC}(\mathrm{mmol} / \mathrm{L})$ & $5.2 \pm 1$ & $5.3 \pm 0.9$ & $5.3 \pm 0.9$ & 0.007 & $5.3 \pm 0.9$ & $5.2 \pm 0.9$ & $5.2 \pm 0.8$ & 0.000 & $5.3 \pm 0.9$ & $5.3 \pm 0.9$ & $5.2 \pm 0.9$ & 0.000 \\
\hline HDL-C (mmol/L) & $1.3 \pm 0.4$ & $1.3 \pm 0.4$ & $1.2 \pm 0.4$ & 0.000 & $1.2 \pm 0.4$ & $1.3 \pm 0.4$ & $1.3 \pm 0.4$ & 0.000 & $1.2 \pm 0.4$ & $1.3 \pm 0.4$ & $1.3 \pm 0.4$ & 0.000 \\
\hline LDL-C (mmol/L) & $3.6 \pm 0.9$ & $3.7 \pm 0.8$ & $3.7 \pm 0.9$ & 0.000 & $3.7 \pm 0.9$ & $3.6 \pm 0.8$ & $3.6 \pm 0.8$ & 0.000 & $3.7 \pm 0.9$ & $3.7 \pm 0.9$ & $3.6 \pm 0.8$ & 0.000 \\
\hline Serum TG $(\mathrm{mmol} / \mathrm{L})$ & $1.8 \pm 1.1$ & $2.0 \pm 1.3$ & $2.0 \pm 1.5$ & 0.000 & $2.1 \pm 1.3$ & $1.9 \pm 1.2$ & $1.9 \pm 1.4$ & 0.000 & $2.1 \pm 1.4$ & $1.9 \pm 1.3$ & $1.9 \pm 1.2$ & 0.000 \\
\hline FPG (mmol/L) & $6.1 \pm 1.5$ & $6.2 \pm 1.6$ & $6.6 \pm 2.3$ & 0.000 & $6.5 \pm 2.2$ & $6.3 \pm 1.8$ & $6.1 \pm 1.5$ & 0.000 & $6.4 \pm 2$ & $6.4 \pm 1.9$ & $6.1 \pm 1.5$ & 0.000 \\
\hline CRP (nmol/L) & $29.7 \pm 47.7$ & $32.0 \pm 43.3$ & $32.0 \pm 45.6$ & 0.001 & $30.9 \pm 45.7$ & $30.4 \pm 44.6$ & $28.3 \pm 37.4$ & 0.000 & $31.9 \pm 42.3$ & $31.9 \pm 41.1$ & $27.7 \pm 39.0$ & 0.000 \\
\hline
\end{tabular}

BMI: body mass index, WC: waist circumference, BP: blood pressure, TC: total cholesterol, HDL-C: high-density lipoprotein-cholesterol, LDL-C: low-density lipoprotein-cholesterol,

TG: triacylglycerol, FPG: fasting plasma glucose, CRP: C-reactive protein. ${ }^{1}$ Data are presented as the mean $\pm \mathrm{SD}$ for continuous variables and $n(\%)$ for categorical variables. ${ }^{2} p$-values

were derived from general linear regression for continuous variables and from chi-square test for categorical variables. 
Table 3. Odds ratios (95\% confidence intervals) for components of metabolic syndrome ${ }^{1}$ and C-reactive protein ${ }^{2}$ across tertiles of dietary patterns.

\begin{tabular}{|c|c|c|c|c|c|c|c|}
\hline \multirow{2}{*}{$\begin{array}{l}\text { Components of } \\
\text { Metabolic Syndrome }\end{array}$} & & \multicolumn{2}{|c|}{ Meat-Instant Food Dietary Pattern } & \multirow{2}{*}{$\begin{array}{c}\text { Vege-Seafood Dietary Pattern } \\
\text { Model } 1\end{array}$} & \multicolumn{3}{|c|}{ Cereal-Dairy Dietary Pattern } \\
\hline & & Model $1^{3}$ & Model $2^{4}$ & & Model 2 & Model 1 & Model 2 \\
\hline \multirow{4}{*}{ High level of WC (male) } & T1 & 1 & 1 & 1 & 1 & 1 & 1 \\
\hline & T2 & $1.293(1.185-1.412)$ & $1.288(1.180-1.407)$ & $0.820(0.756-0.890)$ & $0.827(0.762-0.897)$ & $0.974(0.900-1.054)$ & $0.982(0.907-1.064)$ \\
\hline & $\mathrm{T} 3$ & $1.480(1.360-1.611)$ & $1.479(1.358-1.610)$ & $0.593(0.545-0.646)$ & $0.601(0.552-0.654)$ & $0.777(0.717-0.843)$ & $0.778(0.717-0.844)$ \\
\hline & $p$ & 0.000 & 0.000 & 0.000 & 0.000 & 0.000 & 0.000 \\
\hline \multirow{4}{*}{ High level of WC (female) } & $\mathrm{T} 1$ & 1 & 1 & 1 & 1 & 1 & 1 \\
\hline & T2 & $1.527(1.400-1.666)$ & $1.512(1.386-1.649)$ & $0.843(0.768-0.924)$ & $0.837(0.763-0.919)$ & $1.003(0.916-1.099)$ & $0.993(0.907-1.089)$ \\
\hline & T3 & $1.949(1.777-2.138)$ & $1.889(1.720-2.074)$ & $0.816(0.746-0.892)$ & $0.811(0.741-0.888)$ & $0.884(0.808-0.968)$ & $0.882(0.806-0.996)$ \\
\hline & $p$ & 0.000 & 0.000 & 0.006 & 0.008 & 0.000 & 0.000 \\
\hline \multirow{4}{*}{ High level of systolic BP } & T1 & 1 & 1 & 1 & 1 & 1 & 1 \\
\hline & T2 & $1.180(1.111-1.254)$ & $1.038(0.973-1.107)$ & $0.912(0.859-0.969)$ & $0.898(0.844-0.956)$ & $1.053(0.991-1.119)$ & $0.988(0.928-1.051)$ \\
\hline & T3 & $1.240(1.167-1.318)$ & $1.049(0.985-1.117)$ & $0.868(0.817-0.922)$ & $0.843(0.792-0.897)$ & $1.066(1.004-1.132)$ & $1.041(0.979-1.108)$ \\
\hline & $p$ & 0.000 & 0.337 & 0.000 & 0.000 & 0.088 & 0.215 \\
\hline \multirow{4}{*}{ High level of diastolic BP } & T1 & 1 & 1 & 1 & 1 & 1 & 1 \\
\hline & T2 & $1.008(0.937-1.084)$ & $1.020(0.946-1.099)$ & $0.838(0.781-0.900)$ & $0.837(0.779-0.899)$ & $1.071(0.998-1.149)$ & $1.077(1.004-1.155)$ \\
\hline & T3 & $1.073(0.999-1.152)$ & $1.069(0.995-1.150)$ & $0.817(0.760-0.877)$ & $0.817(0.761-0.878)$ & $0.776(0.721-0.835)$ & $0.788(0.732-0.849)$ \\
\hline & $p$ & 0.142 & 0.207 & 0.000 & 0.000 & 0.000 & 0.000 \\
\hline \multirow{4}{*}{$\begin{array}{l}\text { Low level of HDL-C } \\
\text { (male) }\end{array}$} & $\mathrm{T} 1$ & 1 & 1 & 1 & 1 & 1 & 1 \\
\hline & $\mathrm{T} 2$ & $1.370(1.250-1.501)$ & $1.318(1.202-1.446)$ & $0.609(0.559-0.663)$ & $0.620(0.569-0.676)$ & $0.939(0.860-1.025)$ & $0.929(0.851-1.015)$ \\
\hline & T3 & $1.447(1.318-1.501)$ & $1.453(1.322-1.597)$ & $0.573(0.525-0.625)$ & $0.584(0.535-0.638)$ & $0.883(0.809-0.964)$ & $0.894(0.818-0.977)$ \\
\hline & $p$ & 0.000 & 0.000 & 0.000 & 0.000 & 0.022 & 0.044 \\
\hline \multirow{4}{*}{$\begin{array}{l}\text { Low level of HDL-C } \\
\text { (female) }\end{array}$} & T1 & 1 & 1 & 1 & 1 & 1 & 1 \\
\hline & $\mathrm{T} 2$ & $1.147(1.052-1.252)$ & $1.100(1.007-1.201)$ & $0.823(0.751-0.903)$ & $0.792(0.722-0.870)$ & $0.905(0.826-0.993)$ & $0.864(0.787-0.949)$ \\
\hline & T3 & $1.515(1.382-1.661)$ & $1.392(1.268-1.529)$ & $0.843(0.770-0.924)$ & $0.833(0.760-0.914)$ & $0.810(0.740-0.886)$ & $0.764(0.697-0.838)$ \\
\hline & $P$ & 0.000 & 0.000 & 0.000 & 0.000 & 0.000 & 0.000 \\
\hline \multirow{4}{*}{ High level of serum TG } & T1 & 1 & 1 & 1 & 1 & 1 & 1 \\
\hline & T2 & $1.264(1.190-1.343)$ & $1.122(1.054-1.194)$ & $0.803(0.757-0.853)$ & $0.824(0.776-0.875)$ & $0.823(0.776-0.874)$ & $0.835(0.786-0.886)$ \\
\hline & $\mathrm{T} 3$ & $1.356(1.276-1.440)$ & $1.281(1.205-1.361)$ & $0.711(0.670-0.755)$ & $0.742(0.699-0.789)$ & $0.780(0.735-0.828)$ & $0.812(0.764-0.862)$ \\
\hline & $p$ & 0.000 & 0.000 & 0.000 & 0.000 & 0.000 & 0.000 \\
\hline \multirow{4}{*}{ High level of FPG } & T1 & 1 & 1 & 1 & 1 & 1 & 1 \\
\hline & $\mathrm{T} 2$ & $1.251(1.172-1.335)$ & $1.318(1.230-1.412)$ & $0.821(0.769-0.876)$ & $0.803(0.751-0.859)$ & $1.079(1.011-1.152)$ & $1.078(1.008-1.153)$ \\
\hline & $\mathrm{T} 3$ & $1.239(1.161-1.322)$ & $1.255(1.173-1.342)$ & $0.885(0.829-0.945)$ & $0.887(0.829-0.949)$ & $0.914(0.857-0.975)$ & $0.929(0.750-0.857)$ \\
\hline & $p$ & 0.000 & 0.000 & 0.000 & 0.000 & 0.000 & 0.000 \\
\hline \multirow{4}{*}{ High level of CRP } & $\mathrm{T} 1$ & 1 & 1 & 1 & 1 & 1 & 1 \\
\hline & T2 & $0.891(0.817-0.973)$ & $0.978(0.893-1.071)$ & $0.748(0.691-0.810)$ & $0.761(0.702-0.825)$ & $1.054(0.973-1.142)$ & $1.060(0.978-1.149)$ \\
\hline & T3 & $1.201(1.106-1.304)$ & $1.257(1.156-1.367)$ & $0.739(0.683-0.799)$ & $0.740(0.699-0.801)$ & $0.965(0.854-1.062)$ & $0.980(0.902-1.085)$ \\
\hline & $p$ & 0.000 & 0.000 & 0.000 & 0.000 & 0.000 & 0.000 \\
\hline
\end{tabular}

The odds ratios across tertiles of dietary patterns were compared to the reference group (T1). WC: waist circumference, BP: blood pressure, HDL-C: high-density lipoprotein-cholesterol, TG: triacylglycerol, FPG: fasting plasma glucose, CRP: C-reactive protein. ${ }^{1}$ Components of metabolic syndrome were defined as a high level of WC (mean) ( $>95.8 \mathrm{~cm}$ for males and $\geq 85.2 \mathrm{~cm}$ for females), a high level of systolic BP $(\geq 130 \mathrm{mmHg})$, a high level of diastolic BP ( $\geq 85 \mathrm{mmHg})$, a low level of HDL-C ( $<1.03 \mathrm{mmol} / \mathrm{L}$ for males and $<1.29 \mathrm{mmol} / \mathrm{L}$ for females), a high level of serum TG ( $\geq 1.70 \mathrm{mmol} / \mathrm{L}$ ), a and high level of FPG ( $\geq 5.60 \mathrm{mmol} / \mathrm{L}$ ). ${ }^{2}$ High level of CRP was defined as $\geq 28.6 \mathrm{nmol} / \mathrm{L} .{ }^{3}$ Unadjusted. ${ }^{4}$ Adjusted for age, gender (except WC and HDL-C), education, marital status, smoking, and drinking. 


\section{Discussion}

Our study revealed that the meat-instant food dietary pattern was positively correlated with the components of MetS and CRP among Taiwanese people aged 35 years and above with MetS, while the vege-seafood and cereal-dairy dietary patterns were inversely associated. The meat-instant food dietary pattern was characterized as high in animal protein, saturated fat, sweets, sodium, and food additives. Hence, it was more similar to the Western or unhealthy dietary pattern [24,31]. Consistent with our results, the Western dietary pattern-which is high in saturated fat-was positively correlated with MetS [22,32]. Intake of saturated fat had a positive association with abnormal lipoprotein levels and increased blood lipids and blood pressure [33]. Additionally, high intake of sweets and sugary beverages increased insulin resistance and central obesity [34,35]. The previous study also found that high intake of meat-especially organ meat and processed meat-was strongly correlated with MetS and CVD [36]. Our results suggested that the meat-instant food dietary pattern was more likely to be adopted by younger men, current smokers, or those who were drinking. Similarly, both the Western dietary pattern and unhealthy lifestyles such as smoking and drinking were highly associated with MetS and its components [37,38].

The vege-seafood dietary pattern, which was high in dietary fibers, vitamins, minerals, and unsaturated fat, was comparable to the healthy dietary pattern. The healthy dietary pattern had a protective effect against MetS and its components [39] and CVD [40]. The Mediterranean dietary pattern is associated with decreased risk of MetS. It is rich in fruit, vegetables, fish, and legumes [41]. The components of the healthy dietary pattern such as dietary fiber, vitamins, minerals, mono-, and poly-unsaturated fat may improve insulin sensitivity, increase antioxidative defense, reduce the risk of metabolic disorder, and decrease fatty liver disease [42-44].

Comparable with the healthy dietary pattern, the cereal-dairy dietary pattern was characterized as being rich in dietary fiber, antioxidants, phytochemicals, complex carbohydrates, prebiotics, and probiotics. The previous study demonstrated that the whole cereal dietary pattern with high intake of whole grains and whole wheat provided abundant sources of dietary fiber and antioxidants, which was beneficial to health promotion [45]. Previous studies also showed that both whole grains and whole wheat as a prebiotic regulated body weight and insulin action [45-47]. Overall, dietary pattern appears to more effectively mediate health problems than individual food items, although some food items had significant effects on health status. Therefore, the inverse association of the vege-seafood or cereal-dairy dietary pattern with the components of MetS and CRP could be attributed to the individual's overall dietary pattern, rather than single food items.

The meat-instant food dietary pattern had a positive association with CRP, which is a marker of inflammation that can predict CVD [4]. Consistent with our results, previous studies in China and Iran showed that the Western dietary pattern characterized by high intake of red meat, processed meat, butter, high-fat dairy products, sweets, and soft drinks positively correlated with CRP levels [48,49]. Our findings also showed that the vege-seafood or cereal-dairy dietary pattern was inversely associated with CRP levels. They suggested that healthy dietary patterns such as vege-seafood or cereal-dairy dietary pattern had beneficial effects on inflammatory regulation. Similarly, high intake of fruits and vegetables revealed a significantly inverse association with CRP levels [50,51]. Additionally, a randomized controlled clinical trial suggested that probiotics and prebiotics as functional food reduced inflammatory markers such as CRP in patients with type 2 diabetes $[52,53]$. The prudent pattern-characterized by high consumption of dietary fiber and antioxidants-was also correlated with a decreased level of CRP and risk of CVD [54]. The vege-seafood and cereal-dairy dietary patterns were associated with lower inflammatory marker levels, suggesting that these dietary patterns might reduce the risk of inflammation-related chronic diseases [55].

The components of MetS had significantly greater odds of high CRP levels. Consistently, the subjects with MetS had significantly greater odds of elevated CRP levels compared with those without MetS in nondiabetic Cuban Americans [56]. Central obesity and other components of MetS were correlated with increased CRP levels [56]. The International Diabetes Federation suggested that pro-inflammatory states 
including rises in levels of high-sensitivity CRP and cytokines, as well as a decrease in plasma adiponectin levels, needed to be added to clinical metabolic parameters of MetS [57]. A suspected mechanism that increased central adiposity and insulin resistance due to chronic low-grade inflammation of MetS might increase the production of CRP in the liver [58]. After adjusting for dietary patterns and other possible confounding variables, our findings report that the odds of elevated CRP levels tended to decrease slightly, but were still significant in all components of MetS, indicating that dietary patterns consistently had an impact on the correlation between the components of MetS and CRP levels. Dietary patterns might influence not only the homeostasis of pro- and anti-inflammatory cytokines or adipokines, but also the state of low-grade inflammation [59].

According to the IDF definition, central obesity is the first step to defining MetS, followed by the other factors. Central obesity was assessed using waist circumference. Additionally, it was associated with insulin resistance and contributed to MetS and its components. Moreover, significant evidence linked larger waist circumferences with the development of CVD [1] and CRP [60]. In Taiwan, central obesity has become an important issue related to metabolic health. The prevalence of central obesity has increased significantly in Taiwanese middle-aged and older adults [13]. Through this study, we expected to show the problems that central obesity and MetS pose to middle-aged and older adults in Taiwan. To our knowledge, this study is the first of its kind to investigate the association of dietary patterns with components of MetS and inflammation among Taiwanese people aged 35 years and above with MetS. Moreover, this cross-sectional study had a large sample size collected from one institution for a period of 10 years, and the data of the participants included demographic information, lifestyle, dietary intake, anthropometric data, and biochemical measurements, which provided a variety of data information and the homogenization of data analysis. However, we had a limitation in this study. We used a simple self-reported FFQ which only provided an estimation of regular dietary intake. In this retrospective observational study, although the questionnaire provided specific frequencies and portions for each food item, we could not collect the intake of a particular food to calculate the intake of a specific nutrient. Additional studies are needed to explore the association of dietary patterns with MetS and inflammation using a longitudinal study.

\section{Conclusions}

Our findings suggest that diet plays an important role in the management of both MetS and inflammation. On one hand, intake of the meat-instant food dietary pattern was positively associated with components of MetS and CRP. On the other hand, intake of the vege-seafood or cereal-dairy dietary patterns was inversely correlated with components of MetS and CRP.

Supplementary Materials: The following are available online at www.mdpi.com/2072-6643/10/2/143/s1. Table S1. Odds ratios (95\% confidence intervals) of metabolic syndrome components for a high level of C-reactive protein.

Acknowledgments: We would like to acknowledge the Indonesia Endowment Fund for Education (LPDP-BUDI LN), the Ministry of Finance, and the Ministry of Research Technology Higher Education, Republic of Indonesia for offering a scholarship to the first author for his $\mathrm{PhD}$ degree.

Author Contributions: A.S. and J.C.-J.C. conceived, designed, and performed the study; C.-Y.H. and H.-H.R. managed the data set and retrieved the data; A.S., J.C.-J.C., C.-Y.H. and H.-H.R. analyzed the data; and A.S. and J.C.-J.C. wrote the manuscript. All authors have read and approved the final manuscript.

Conflicts of Interest: The authors declare no conflict of interest.

\section{References}

1. Alberti, K.G.M.M.; Zimmet, P.; Shaw, J. The metabolic syndrome-A new worldwide definition. Lancet 2005, 366, 1059-1062. [CrossRef]

2. Deaton, C.; Froelicher, E.S.; Wu, L.H.; Ho, C.; Shishani, K.; Jaarsma, T. The global burden of cardiovascular disease. Eur. J. Cardiovasc. Nurs. 2011, 10 (Suppl. S2), S5-S13. [CrossRef] 
3. Rethorst, C.D.; Bernstein, I.; Trivedi, M.H. Inflammation, obesity and metabolic syndrome in depression: Analysis of the 2009-2010 National Health and Nutrition Survey (NHANES). J. Clin. Psychiatry 2014, 75, e1428. [CrossRef] [PubMed]

4. Ridker, P.M.; Buring, J.E.; Cook, N.R.; Rifai, N. C-reactive protein, the metabolic syndrome, and risk of incident cardiovascular events: An 8-year follow-up of 14719 initially healthy American women. Circulation 2003, 107, 391-397. [CrossRef] [PubMed]

5. Gundogan, K.; Bayram, F.; Capak, M.; Tanriverdi, F.; Karaman, A.; Ozturk, A.; Altunbas, H.; Gokce, C.; Kalkan, A.; Yazici, C. Prevalence of metabolic syndrome in the Mediterranean region of Turkey: Evaluation of hypertension, diabetes mellitus, obesity, and dyslipidemia. Metab. Syndr. Relat. Disord. 2009, 7, 427-434. [CrossRef] [PubMed]

6. Puenpatom, R.A.; Victor, T.W. Increased prevalence of metabolic syndrome in individuals with osteoarthritis: An analysis of NHANES III data. Postgrad. Med. 2009, 121, 9-20. [CrossRef] [PubMed]

7. Beltran-Sanchez, H.; Harhay, M.O.; Harhay, M.M.; McElligott, S. Prevalence and trends of metabolic syndrome in the adult U.S. population, 1999-2010. J. Am. Coll. Cardiol. 2013, 62, 697-703. [CrossRef] [PubMed]

8. Scuteri, A.; Laurent, S.; Cucca, F.; Cockcroft, J.; Cunha, P.G.; Manas, L.R.; Mattace Raso, F.U.; Muiesan, M.L.; Ryliskyte, L.; Rietzschel, E.; et al. Metabolic syndrome across Europe: Different clusters of risk factors. Eur. J. Prev. Cardiol. 2015, 22, 486-491. [CrossRef] [PubMed]

9. Lim, K.G.; Cheah, W.K. A review of metabolic syndrome research in Malaysia. Med. J. Malays. 2016, 71, $20-28$.

10. Sarrafzadegan, N.; Gharipour, M.; Sadeghi, M.; Nezafati, P.; Talaie, M.; Oveisgharan, S.; Nouri, F.; Khosravi, A. Metabolic syndrome and the risk of ischemic stroke. J. Stroke Cerebrovasc. Dis. 2017, 26, 286-294. [CrossRef] [PubMed]

11. Li, R.; Li, W.; Lun, Z.; Zhang, H.; Sun, Z.; Kanu, J.S.; Qiu, S.; Cheng, Y.; Liu, Y. Prevalence of metabolic syndrome in mainland China: A meta-analysis of published studies. BMC Public Health 2016, 16, 296. [CrossRef] [PubMed]

12. Yeh, C.-J.; Chang, H.-Y.; Pan, W.-H. Time trend of obesity, the metabolic syndrome and related dietary pattern in Taiwan: From NAHSIT 1993-1996 to NAHSIT 2005-2008. Asia Pac. J. Clin. Nutr. 2011, 20, $292-300$. [PubMed]

13. Hwang, L.C.; Bai, C.H.; Chen, C.J. Prevalence of obesity and metabolic syndrome in Taiwan. J. Formos. Med. Assoc. 2006, 105, 626-635. [CrossRef]

14. Mirmiran, P.; Noori, N.; Azizi, F. A prospective study of determinants of the metabolic syndrome in adults. Nutr. Metab. Cardiovasc. Dis. 2008, 18, 567-573. [CrossRef] [PubMed]

15. Wilsgaard, T.; Jacobsen, B.K. Lifestyle factors and incident metabolic syndrome: The Tromsø Study 1979-2001. Diab. Res. Clin. Pract. 2007, 78, 217-224. [CrossRef] [PubMed]

16. Calton, E.K.; James, A.P.; Pannu, P.K.; Soares, M.J. Certain dietary patterns are beneficial for the metabolic syndrome: Reviewing the evidence. Nutr. Res. 2014, 34, 559-568. [CrossRef] [PubMed]

17. Newby, P.K.; Tucker, K.L. Empirically derived eating patterns using factor or cluster analysis: A review. Nutr Rev. 2004, 62, 177-203. [CrossRef] [PubMed]

18. Djousse, L.; Padilla, H.; Nelson, T.L.; Gaziano, J.M.; Mukamal, K.J. Diet and metabolic syndrome. Endocr. Metab. Immune Disord. Drug Targets 2010, 10, 124-137. [CrossRef] [PubMed]

19. Hong, S.; Song, Y.; Lee, K.H.; Lee, H.S.; Lee, M.; Jee, S.H.; Joung, H. A fruit and dairy dietary pattern is associated with a reduced risk of metabolic syndrome. Metabolism 2012, 61, 883-890. [CrossRef] [PubMed]

20. Asghari, G.; Yuzbashian, E.; Mirmiran, P.; Hooshmand, F.; Najafi, R.; Azizi, F. Dietary approaches to stop hypertension (DASH) dietary pattern is associated with reduced incidence of metabolic syndrome in children and adolescents. J. Pediatr. 2016, 174, 178-184.e171. [CrossRef] [PubMed]

21. Rumawas, M.E.; Meigs, J.B.; Dwyer, J.T.; McKeown, N.M.; Jacques, P.F. Mediterranean-style dietary pattern, reduced risk of metabolic syndrome traits, and incidence in the Framingham Offspring Cohort. Am. J. Clin. Nutr. 2009, 90, 1608-1614. [CrossRef] [PubMed]

22. Esmaillzadeh, A.; Kimiagar, M.; Mehrabi, Y.; Azadbakht, L.; Hu, F.B.; Willett, W.C. Dietary patterns, insulin resistance, and prevalence of the metabolic syndrome in women. Am. J. Clin. Nutr. 2007, 85, 910-918. [PubMed]

23. Giugliano, D.; Ceriello, A.; Esposito, K. The effects of diet on inflammation. J. Am. Coll. Cardiol. 2006, 48, 677-685. [CrossRef] [PubMed] 
24. Muga, M.A.; Owili, P.O.; Hsu, C.Y.; Rau, H.H.; Chao, J.C. Association between dietary patterns and cardiovascular risk factors among middle-aged and elderly adults in Taiwan: A population-based study from 2003 to 2012. PLoS ONE 2016, 11, e0157745. [CrossRef] [PubMed]

25. Tsai, H.J. Dietary patterns and cognitive decline in Taiwanese aged 65 years and older. Int. J. Geriatr. Psychiatry 2015, 30, 523-530. [CrossRef] [PubMed]

26. Lo, Y.T.; Wahlqvist, M.L.; Huang, Y.C.; Lee, M.S. Elderly Taiwanese who spend more on fruits and vegetables and less on animal-derived foods use less medical services and incur lower medical costs. Br. J. Nutr. 2016, 115, 823-833. [CrossRef] [PubMed]

27. Tourlouki, E.; Matalas, A.-L.; Panagiotakos, D.B. Dietary habits and cardiovascular disease risk in middle-aged and elderly populations: A review of evidence. Clin. Interv. Aging 2009, 4, 319-330. [CrossRef] [PubMed]

28. Liu, C.Y.; Chou, Y.C.; Chao, J.C.; Hsu, C.Y.; Cha, T.L.; Tsao, C.W. The association between dietary patterns and semen quality in a general Asian population of 7282 Males. PLoS ONE 2015, 10, e0134224. [CrossRef] [PubMed]

29. Pearson, T.A.; Mensah, G.A.; Hong, Y.; Smith, S.C., Jr. CDC/AHA workshop on markers of inflammation and cardiovascular disease: Application to clinical and public health practice: Overview. Circulation 2004, 110, 543-544. [CrossRef] [PubMed]

30. Friedewald, W.T.; Levy, R.I.; Fredrickson, D.S. Estimation of the concentration of low-density lipoprotein cholesterol in plasma, without use of the preparative ultracentrifuge. Clin. Chem. 1972, 18, 499-502. [PubMed]

31. Amini, M.; Esmaillzadeh, A.; Shafaeizadeh, S.; Behrooz, J.; Zare, M. Relationship between major dietary patterns and metabolic syndrome among individuals with impaired glucose tolerance. Nutrition 2010, 26, 986-992. [CrossRef] [PubMed]

32. Farhangi, M.A.; Jahangiry, L.; Asghari-Jafarabadi, M.; Najafi, M. Association between dietary patterns and metabolic syndrome in a sample of Tehranian adults. Obes. Res. Clin. Pract. 2016, 10, 64-73. [CrossRef] [PubMed]

33. Riccardi, G.; Giacco, R.; Rivellese, A.A. Dietary fat, insulin sensitivity and the metabolic syndrome. Clin. Nutr. 2004, 23, 447-456. [CrossRef] [PubMed]

34. Wirfalt, E.; Hedblad, B.; Gullberg, B.; Mattisson, I.; Andren, C.; Rosander, U.; Janzon, L.; Berglund, G. Food patterns and components of the metabolic syndrome in men and women: A cross-sectional study within the Malmo diet and cancer cohort. Am. J. Epidemiol. 2001, 154, 1150-1159. [CrossRef] [PubMed]

35. Liao, C.H.; Shaw, H.M.; Chao, P.M. Impairment of glucose metabolism in mice induced by dietary oxidized frying oil is different from that induced by conjugated linoleic acid. Nutrition 2008, 24, 744-752. [CrossRef] [PubMed]

36. Gadgil, M.D.; Anderson, C.A.; Kandula, N.R.; Kanaya, A.M. Dietary patterns are associated with metabolic risk factors in South Asians living in the United States. J. Nutr. 2015, 145, 1211-1217. [CrossRef] [PubMed]

37. Baik, I.; Shin, C. Prospective study of alcohol consumption and metabolic syndrome. Am. J. Clin. Nutr. 2008, 87, 1455-1463. [PubMed]

38. Athyros, V.G.; Liberopoulos, E.N.; Mikhailidis, D.P.; Papageorgiou, A.A.; Ganotakis, E.S.; Tziomalos, K.; Kakafika, A.I.; Karagiannis, A.; Lambropoulos, S.; Elisaf, M. Association of drinking pattern and alcohol beverage type with the prevalence of metabolic syndrome, diabetes, coronary heart disease, stroke, and peripheral arterial disease in a Mediterranean cohort. Angiology 2008, 58, 689-697. [CrossRef] [PubMed]

39. Castanho, G.K.; Marsola, F.C.; McLellan, K.C.; Nicola, M.; Moreto, F.; Burini, R.C. Consumption of fruit and vegetables associated with the metabolic syndrome and its components in an adult population sample. Cien. Saude Colet. 2013, 18, 385-392. [CrossRef] [PubMed]

40. Hartley, L.; Igbinedion, E.; Holmes, J.; Flowers, N.; Thorogood, M.; Clarke, A.; Stranges, S.; Hooper, L.; Rees, K. Increased consumption of fruit and vegetables for the primary prevention of cardiovascular diseases. Cochrane Database Syst. Rev. 2013, Cd009874. [CrossRef] [PubMed]

41. Viscogliosi, G.; Cipriani, E.; Liguori, M.L.; Marigliano, B.; Saliola, M.; Ettorre, E.; Andreozzi, P. Mediterranean dietary pattern adherence: Associations with prediabetes, metabolic syndrome, and related microinflammation. Metab. Syndr. Relat. Disord. 2013, 11, 210-216. [CrossRef] [PubMed]

42. Fernandez, M.L.; West, K.L. Mechanisms by which dietary fatty acids modulate plasma lipids. J. Nutr. 2005, 135, 2075-2078. [CrossRef] [PubMed] 
43. Lopez, S.; Bermudez, B.; Ortega, A.; Varela, L.M.; Pacheco, Y.M.; Villar, J.; Abia, R.; Muriana, F.J. Effects of meals rich in either monounsaturated or saturated fat on lipid concentrations and on insulin secretion and action in subjects with high fasting triglyceride concentrations. Am. J. Clin. Nutr. 2011, 93, 494-499. [CrossRef] [PubMed]

44. Cantero, I.; Abete, I.; Monreal, J.I.; Martinez, J.A.; Zulet, M.A. Fruit fiber consumption specifically improves liver health status in obese subjects under energy restriction. Nutrients 2017, 9, 667. [CrossRef] [PubMed]

45. Karl, J.P.; Saltzman, E. The role of whole grains in body weight regulation. Adv. Nutr. 2012, 3, 697-707. [CrossRef] [PubMed]

46. Vetrani, C.; Costabile, G.; Luongo, D.; Naviglio, D.; Rivellese, A.A.; Riccardi, G.; Giacco, R. Effects of whole-grain cereal foods on plasma short chain fatty acid concentrations in individuals with the metabolic syndrome. Nutrition 2016, 32, 217-221. [CrossRef] [PubMed]

47. Vitaglione, P.; Mennella, I.; Ferracane, R.; Rivellese, A.A.; Giacco, R.; Ercolini, D.; Gibbons, S.M.; La Storia, A.; Gilbert, J.A.; Jonnalagadda, S. Whole-grain wheat consumption reduces inflammation in a randomized controlled trial on overweight and obese subjects with unhealthy dietary and lifestyle behaviors: Role of polyphenols bound to cereal dietary fiber. Am. J. Clin. Nutr. 2015, 101, 251-261. [CrossRef] [PubMed]

48. Villegas, R.; Xiang, Y.-B.; Cai, H.; Elasy, T.; Cai, Q.; Zhang, X.; Fazio, S.; Linton, M.; Li, H.; Xu, W.H. Lifestyle determinants of C-reactive protein in middle-aged, urban Chinese men. Nutr. Metab. Cardiovasc. Dis. 2012, 22, 223-230. [CrossRef] [PubMed]

49. Esmaillzadeh, A.; Kimiagar, M.; Mehrabi, Y.; Azadbakht, L.; Hu, F.B.; Willett, W.C. Dietary patterns and markers of systemic inflammation among Iranian women. J. Nutr. 2007, 137, 992-998. [CrossRef] [PubMed]

50. Esmaillzadeh, A.; Kimiagar, M.; Mehrabi, Y.; Azadbakht, L.; Hu, F.B.; Willett, W.C. Fruit and vegetable intakes, C-reactive protein, and the metabolic syndrome. Am. J. Clin. Nutr. 2006, 84, 1489-1497. [PubMed]

51. Hajihashemi, P.; Azadbakht, L.; Hashemipor, M.; Kelishadi, R.; Esmaillzadeh, A. Whole-grain intake favorably affects markers of systemic inflammation in obese children: A randomized controlled crossover clinical trial. Mol. Nutr. Food Res. 2014, 58, 1301-1308. [CrossRef] [PubMed]

52. Asemi, Z.; Zare, Z.; Shakeri, H.; Sabihi, S.S.; Esmaillzadeh, A. Effect of multispecies probiotic supplements on metabolic profiles, hs-CRP, and oxidative stress in patients with type 2 diabetes. Ann. Nutr. Metab. 2013, 63, 1-9. [CrossRef] [PubMed]

53. Dehghan, P.; Pourghassem Gargari, B.; Asghari Jafar-abadi, M. Oligofructose-enriched inulin improves some inflammatory markers and metabolic endotoxemia in women with type 2 diabetes mellitus: A randomized controlled clinical trial. Nutrition 2014, 30, 418-423. [CrossRef] [PubMed]

54. Lopez-Garcia, E.; Schulze, M.B.; Fung, T.T.; Meigs, J.B.; Rifai, N.; Manson, J.E.; Hu, F.B. Major dietary patterns are related to plasma concentrations of markers of inflammation and endothelial dysfunction. Am. J. Clin. Nutr. 2004, 80, 1029-1035. [PubMed]

55. Wang, Z.; Hoy, W.E. C-reactive protein: An independent predictor of cardiovascular disease in Aboriginal Australians. Aust. N. Z. J. Public Health 2010, 34, 25-29. [CrossRef] [PubMed]

56. Huffman, F.G.; Gomez, G.P.; Zarini, G.G. Metabolic syndrome and high-sensitivity C-reactive protein in Cubans. Ethn. Dis. 2009, 19, 115-120. [PubMed]

57. Den Engelsen, C.; Koekkoek, P.S.; Gorter, K.J.; van den Donk, M.; Salome, P.L.; Rutten, G.E. High-sensitivity C-reactive protein to detect metabolic syndrome in a centrally obese population: A cross-sectional analysis. Cardiovasc. Diabetol. 2012, 11, 25. [CrossRef] [PubMed]

58. Farooq, W.; Farwa, U.; Khan, F.R. The metabolic syndrome and inflammation: Role of insulin resistance and increased adiposity. Oman Med. J. 2015, 30, 100-103. [CrossRef] [PubMed]

59. Calder, P.C.; Ahluwalia, N.; Brouns, F.; Buetler, T.; Clement, K.; Cunningham, K.; Esposito, K.; Jönsson, L.S.; Kolb, H.; Lansink, M. Dietary factors and low-grade inflammation in relation to overweight and obesity. Br. J. Nutr. 2011, 106, 1-78. [CrossRef] [PubMed]

60. Chen, S.; Liu, H.; Liu, X.; Li, Y.; Li, M.; Liang, Y.; Shao, X.; Holthofer, H.; Zou, H. Central obesity, C-reactive protein and chronic kidney disease: A community-based cross-sectional study in southern China. Kidney Blood Press. Res. 2013, 37, 392-401. [CrossRef] [PubMed]

(C) 2018 by the authors. Licensee MDPI, Basel, Switzerland. This article is an open access article distributed under the terms and conditions of the Creative Commons Attribution (CC BY) license (http:/ / creativecommons.org/licenses/by/4.0/). 